\title{
New Paradigm of Outcome-Based Education - A Higher Education Boon
}

\author{
Dr.K. Bala Sathya ${ }^{a}$, G. Ganesh Narayanan ${ }^{\text {b }}$ \\ ${ }^{a}$ Assistant Professor, Department of Commerce (Aided), Mannar Thirumalai Naicker College, Madurai, India. \\ ${ }^{\mathrm{b}}$ Assistant General Manager, G\&R Fusion Pte. Ltd., Robertson Quay, Singapore.
}

Article History: Received: 11 January 2021; Accepted: 27 February 2021; Published online: 5 April 2021

\begin{abstract}
Outcome-Based Education (OBE) is a vibrant model and considered as a giant leap forward to improve higher education and assists all graduates contend with their global counterparts. It is a student-centered tutoring conception that focuses on measuring student performance through outcomes. The Higher Education Institutions should frame appropriate course outcome, program outcome and these outcome should correlate with institutional objectives. But the actual success lies in the effective implementation and rigid accreditation process to ensure the quality of education. Hence, it is imperative to analyze the strength, weakness of the model and practical difficulties in case of implementation. This study reveals basic concepts, Implementation Strategies and OBE Practices and standards. The OBE-Steering Committee in each HEI offers ideas to frame Newfangled Curriculum with finest outcome and effective teaching methods with ICT tools and evaluation pattern based on blooms taxonomy.
\end{abstract}

Keywords: Outcome-based Education, Curriculum Development, Teaching Methods, Learning Outcomes, Higher Education Reforms.

\section{Introduction}

Education is perhaps one of the most important ingredients to a blissful, victorious and constructive life. A good education system provides enormous skills for all learners to overcome their real life problems and obstacles. Due to Globalization and technological advancements, the Higher Education System followed in India need to be restructured to face challenges and to seize the opportunities. The Implementation of OBE at Arts \& Science and Engineering Institutions is measured to be a great step forward for higher education in India

\section{Outcome-based Education System}

Outcome-Based Education (OBE) is considered as a vibrant model which is being adopted at a fast pace at higher education level in India. It is considered as a giant leap forward to improve higher education and assists all graduates contend with their global counterparts. It is a student-centered tutoring model that focuses on measuring student performance through outcomes. An outcome comprises knowledge, skills and attitudes. Its focuses on evaluation of outcomes of the program by stating the knowledge, skill and behavior a graduate are expected to attain upon completion of a program. OBE model is a student-centric teaching and learning methodology in which the program offered by the higher education institutions, course delivery and assessment are planned to attain the declared objectives and results.

\section{Objectives}

The following objectives were drawn to fulfill the aim of the study:

- To examine the Association between variables.

- To explore the significant impact factors on implementation of OBE model.

- To analyze the noticeable consequences after implementation in teaching and learning process.

\section{Significance of the Study}

Outcome based Education is a new paradigm which is considered as an important solution to improve standard in higher education. Now-a-days, All Higher Education Institutions (HEI) was compelled to implement $\mathrm{OBE}$ in their institution to provide best outcomes. In the current scenario, all HEI's should offer high standard of education as it is vital factor to produce capable professionals, therefore building a strong nation and getting along with global competition. This study has been carried out to get a clear picture of the consciousness of staff members and their attitude towards OBE. This research may also reveal the strength and weakness of the model.

\section{Research Design}

Primary data are collected through structured questionnaire and secondary data are collected through Books and Journals. Samples were selected by applying convenience random sampling method. The collected data were analyzed by applying statistical tools such as chi-square test, Garrett Ranking method and Factor Analysis. 


\section{Analysis}

\subsection{Chi-square Analysis}

The following table shows the association between variables, such as Respondents Level of Awareness (LOA) with Age and Gender.

\begin{tabular}{|c|c|c|c|c|c|}
\hline S.No. & & ameters & Value & Df. & $\begin{array}{c}\text { Asymp. Sig. } \\
\text { (2-sided) }\end{array}$ \\
\hline \multirow[t]{2}{*}{1.} & Age \& LOA & Pearson Chi-Square & $3.742^{\mathrm{a}}$ & 6 & .712 \\
\hline & & $\begin{array}{l}\text { Likelihood Ratio } \\
\mathbf{N} \text { of Valid Cases }\end{array}$ & 3.942 & 6 & .685 \\
\hline \multirow[t]{2}{*}{2.} & Gender \& LOA & Pearson Chi-Square & $.723^{\mathrm{a}}$ & 2 & 697 \\
\hline & & $\begin{array}{l}\text { Likelihood Ratio } \\
\mathbf{N} \text { of Valid Cases }\end{array}$ & .722 & 2 & 697 \\
\hline
\end{tabular}

\begin{tabular}{llcc}
\hline S.No. & Parameters & P-Value & Sig. level \\
\hline 1. & Age \& LOA & 0.711543 & Not significant \\
2. & Gender \& LOA & 0.696631 & Not significant \\
\hline
\end{tabular}

In order to test the relationship between variables chi-square test has been applied. A chi-square test of independence showed that there was no significant association between AGE with Level of Awareness (LOA) and GENDER with Level of Awareness (LOA).

\subsection{Analysis of Factors that Enhances Implementation of OBE}

The following table shows the average score and rank secured by the impact factors:

\begin{tabular}{lll}
\hline \multicolumn{1}{c}{ FACTORS (STEERING COMMITTEE) } & AVERAGE & RANK \\
& SCORE & \\
\hline Experienced Leaders \& Advisers & $\mathbf{7 0 . 1 1}$ & $\mathbf{1}$ \\
Highly experienced pedagogue(educationist) & $\mathbf{6 6 . 1 2}$ & $\mathbf{2}$ \\
Key Staff Members & $\mathbf{6 4 . 5 2}$ & $\mathbf{3}$ \\
Experts from leading Institutions & $\mathbf{6 4 . 4 1}$ & $\mathbf{4}$ \\
Knowledge Enrichment through Effective Workshops \& & $\mathbf{5 9 . 8 4}$ & $\mathbf{5}$ \\
Meetings with core officials & & \\
\hline
\end{tabular}

According to this review of the Garrett Ranking analysis, Experienced Leaders \& Advisers are considered as the most important factor for enhancing OBE Implementation. In order to obtain best results from OBE model, the Institution should have highly experienced pedagogue (educationist) \& key staff members. And also opinion of Experts from leading Institutions is needed to enhance OBE implementation. Finally, the Institution should undertake certain initiatives such as workshops \& Meeting with core officials to enrich awareness among staff members.

\subsection{Observable Consequences after Implementation}

The following table shows the Kaiser-Meyer-Olk in Measure to test the noticeable magnitudes after implementation of OBE model.

Teaching and Learning: (Tl)

\begin{tabular}{|c|c|c|c|c|c|c|}
\hline \multirow{2}{*}{$\begin{array}{l}\text { Sr. } \\
\text { No. }\end{array}$} & \multirow[t]{2}{*}{ Statements } & \multicolumn{3}{|c|}{ Initial Eigen values } & \multirow{2}{*}{$\begin{array}{l}\text { Rotated } \\
\text { Component } \\
\text { Matrix }^{\mathrm{a}} \\
\text { Component }^{\text {Compon }}\end{array}$} & \multirow{2}{*}{$\begin{array}{l}\text { Eigen } \\
\text { values }\end{array}$} \\
\hline & & Total & $\begin{array}{c}\% \text { of } \\
\text { Variance }\end{array}$ & Cumulative\% & & \\
\hline 1. & $\begin{array}{l}\text { Helps to attain the learning } \\
\text { outcomes. }\end{array}$ & .802 & 3.645 & 75.122 & .680 & \\
\hline 2. & $\begin{array}{l}\text { Able to improve thestudent's } \\
\text { performance. }\end{array}$ & .709 & 3.222 & 78.344 & .747 & \\
\hline 3. & $\begin{array}{l}\text { Capable to improve teaching } \\
\text { methods. }\end{array}$ & 648 & 2.948 & 81.292 & .727 & 4.417 \\
\hline 4. & Provides aid to improve critical & .606 & 2.754 & 84.045 & .715 & \\
\hline
\end{tabular}


thinking skills through innovative teaching methods.

5. Explained the relationship between .570

86.638

.628 assessments methods (quizzes, tests, assignment, practical test, final exam,

6. Motivate students in self-managed learning.

7. Helps to encourage students to think independently in solving

Kaiser-Meyer-Olkin Measure was applied to verify the observable consequences after implementation of Outcome based education model. The result of the analysis was Kaiser-Meyer-Olkin Measure of Sampling Adequacy $(\mathrm{MSA})=0.632$. From the result it is clear that, the MSA was found to be 0.632 which is greater than 0.5. So the application of factor analysis is suitable in this case. Bartlett's Test of Sphericity shows the result as 595.197 at 0.000 significance level.

\section{Conclusion}

As per UGC guidelines the Higher Education Institutions should submit details on OBE at the time of review. This study conveys idea on framing steering committee and the initiatives to be taken by the committee in case of OBE implementation. The success of OBE model depends on proper formulation of strategy, mission \& vision statement, program outcomes and course outcomes. After origination step, it is essential to impart knowledge regarding OBE and its usefulness to the beneficiaries like staffs and students. This empirical study highlights the improvements in teaching and learning process after implementation. Many Educational Institutions in abroad have adopted this model and have shown best results. To conclude, All HEI's should implement OBE to improve standard of higher education and to compete with other leading Institutions in other countries.

\section{References}

1. Barnett, R., \& Coate, K. (2004). Engaging the curriculum. McGraw-Hill Education (UK).

2. Biggs, J.B. (2011). Teaching for quality learning at university: What the student does. McGraw-hill education (UK).

3. McNeir, G. (1993). Outcomes-Based Education. Research Roundup, 10(1), n1.

4. McPherson, G. (2001). Applying and interpreting statistics: A comprehensive guide (2nd ed.). New York: Springer-Verlag.

5. Adedoyin, Shangodoyin, D.K. (2012). Concepts and practices of outcome based education for effective educational system.

6. Kahn, V.J. (1995). Research in Education, Prentice Hall of India Pvt. Ltd, New Delhi.

7. https://www.urbandictionary.com/define.php?term=OBE

8. https://www.researchgate.net/publication/289715375 